\title{
Roller application of picloram for leafy spurge control in pastures ${ }^{1}$
}

\author{
CALVIN G. MESSERSMITH and RODNEY G. LYM \\ Messersmith and Lym are Professor and Assistant Professor, respectively, Department of Agronomy, North Dakota \\ State University, Fargo, ND 58105.
}

\begin{abstract}
:
Roller-applied picloram (4-amino-3,5,6-trichloropicolinic acid) at a concentration of 30 to $60 \mathrm{~g}$ ae/L gave similar control to leafy spurge (Euphorbia esula L. $\#^{2}$ EPHES) as spray-applied picloram at 1.1 to $2.2 \mathrm{~kg}$ ae/ha. Leafy spurge control was most effective when the roller applicator was adjusted to treat a maximum amount of stem tissue with a $60 \mathrm{~g} / \mathrm{L}$ picloram solution. Control was not improved by including a petroleum oil or surfactant additive. Fall applications of roller-applied picloram tended to provide better control than spring applications. When used on dense leafy spurge stands, the roller applicator applied only $40 \%$ as much picloram as spray treatments of $2.2 \mathrm{~kg} / \mathrm{ha}$. However, picloram residues in soil following roller application were similar to those from picloram at 0.3 to $1.1 \mathrm{~kg} / \mathrm{ha}$ applied as a spray.
\end{abstract}

\section{Introduction}

Almost one-half of the total land area in the United States is used for grazing, and weeds are a universal problem in pasture (7). Economic losses from weeds in pasture and rangeland are difficult to assess but include loss of forage yield and quality, losses of livestock due to plant poisoning and physical injury, and increased costs of management for weed control $(3,7)$. Chemical control has become the most widely used method for removing undesirable shrubs and weeds from grazing lands (10). Control of broadleaf herbaceous weeds is especially difficult because individual species often occur in scattered stands. Herbicide spray application may treat large areas that do not contain the tar-

\footnotetext{
${ }^{1}$ Received for publication April 2, 1984, and in revised form September 6, 1984. Published with the approval of the Director, Agric. Exp. Stn., North Dakota State Univ., as J. Article No. 1355. Cooperative investigation by North Dakota Agric. Exp. Stn., and the U.S. Dep. Agric., Agric. Res. Serv.

${ }^{2}$ Letters following the symbol \# are a WSSA-approved computer code from Important Weeds of the World, 3rd ed., 1983. Available from WSSA, 309 West Clark St., Champaign, IL 61820.
} 
get species. Herbicides applied to nontarget species increase the cost of control and may damage desirable herbage.

Several innovative methods have been developed to control tall weeds in cropland (1, $2,5,9,11)$. The roller applicator dispenses herbicide only on plants directly touched, which avoids herbicide drift and reduces the amount of herbicide used per hectare (11). The cost of weed control in pasture and rangeland could be reduced by limiting herbicide application to target weed species. The purpose of these experiments was to evaluate the potential of roller-applied picloram for leafy spurge control in pasture.

\section{Materials and methods}

Roller and spray applications of picloram were compared for leafy spurge control in pasture and rangeland. The primary component of the roller applicator was a 20-cm-diam pipe covered with a $1.25-\mathrm{cm}$-thick carpet. (Figure 1.) Herbicide solution was applied to the carpet through a plastic pipe located above the roller until the carpet was uniformly moistened. The roller rotated counterclockwise at approximately $50 \mathrm{rpm}$ as the applicator moved forward, thus lifting the weeds for good contact with the carpet. The roller height was adjusted so that the foliage on the upper half of most leafy spurge stems was treated. The ground speed of the applicator was $4.8 \mathrm{~km} / \mathrm{h}$ unless otherwise stated.

Spray treatments were applied with a backpack sprayer in 1978 and 1979 and with a tractor-mounted sprayer in 1980 and 1981, each delivering $80 \mathrm{~L} / \mathrm{ha}$ at $240 \mathrm{kPa}$ and 4.8 $\mathrm{km} / \mathrm{h}$. The herbicide concentrations on the roller were equivalent to picloram at 15,20 , $30,40,60$, and $120 \mathrm{~g}$ ae/L. All experiments were in a randomized complete block design with four replications, and plots were 3 by $8 \mathrm{~m}$. Evaluations were based on visual estimate of percent stand reduction compared to the control.

\section{Leafy spurge control}

The first experiment was established on June 21, 1978, in a permanent pasture with Kentucky bluegrass (Poa pratensis L.) as the predominant species. The leafy spurge was 55 to $70 \mathrm{~cm}$ tall and was beginning to set seed.

The second experiment was established in a permanent pasture on September 22, 1978 , when the leafy spurge was 50 to $60 \mathrm{~cm}$ tall with senesced lower leaves and branches of new fall growth near the stem apex. A foam additive ${ }^{3}$, i.e., a petroleum-based additive normally used as a boom-end, marking foam, at $5 \%(\mathrm{v} / \mathrm{v})$ was added to the picloram solution for two of the roller-applied treatments.

The third experiment was established on October 3, 1979, in an ungrazed pasture area. The leafy spurge was 60 to $75 \mathrm{~cm}$ tall. Approximately 10 to $15 \mathrm{~cm}$ of new stem branches from fall growth was present, but most of the leaves had senesced. A killing frost occurred 6 days after treatments had been applied.

\footnotetext{
${ }^{3}$ Stamfoam, Stam Manufacturing Co., Watseka, IL.
} 


\section{Application variables}

Herbicide solution concentration on the roller, additives with picloram, height of the roller applicator during treatment, and date of application were evaluated for leafy spurge control. The first experiment included roller application of picloram in water at 15, 20, 30, 60, and $120 \mathrm{~g} / \mathrm{L}$ applied on June 16 and September 2, 1980, near Sheldon and Valley City, ND, respectively. The roller was adjusted to treat the top half of most leafy spurge plants.

A second experiment was established on June 16, 1980, to evaluate the effectiveness of additives with roller-applied picloram to increase leafy spurge control. A surfactant at $2.5 \%(\mathrm{v} / \mathrm{v})$ or an oil (83\% paraffin-base petroleum oil plus $15 \%$ emulsifier) at $5 \%(\mathrm{v} / \mathrm{v})$ was added to various picloram concentrations. The leafy spurge was 45 to $60 \mathrm{~cm}$ tall and beginning seed set at treatment time.

A third experiment evaluated picloram application to leafy spurge at three concentrations, two roller applicator heights, and two dates of application. The roller height was adjusted to treat the top half of most leafy spurge plants (high) or as near to the soil surface as the terrain would permit (low). The picloram concentrations in water were 30, 40, and $60 \mathrm{~g} / \mathrm{L}$. Treatments were applied on July 8, 1981, or September 1, 1981.

\section{Rate of picloram applied per hectare}

The rate of herbicide applied with the roller applicator could not be measured accurately on plots $8 \mathrm{~m}$ long, since $8 \mathrm{~L}$ of solution were required to moisten the roller carpet before treatment, but generally less than $1 \%$ was wiped off per plot. Estimates of the rate of herbicide applied by the roller applicator were made on four 0.32- to 0.40-ha areas that had at least an $80 \%$ cover of leafy spurge throughout the treated area. The picloram concentration was $30 \mathrm{~g} / \mathrm{L}$ of water and the roller was kept uniformly moist throughout the treatment. The volume of herbicide solution applied in the measured area was used to calculate the rate per hectare. The treatment was repeated at four different locations.

\section{Picloram residues}

Soil samples were collected from several of the experiments described above at various times after treatment with picloram using roller or conventional spray application. Six soil samples (6 $\mathrm{cm}$ in diameter by $15 \mathrm{~cm}$ deep) per plot were composited, oven dried at $70^{\circ} \mathrm{C}$, and a 500 -g subsample was bioassayed using sunflower (Helianthus annuus L.) as the test species (8). The bioassay detected $>0.1 \mathrm{ppmw}$ of picloram. Soils were sampled in 1980 and 1981. 


\section{Results and discussion}

\section{Leafy spurge control}

Picloram at $30 \mathrm{~g} / \mathrm{L}$ applied on June 21,1978 , with the roller applicator traveling at 4.8 $\mathrm{km} / \mathrm{h}$ gave a similar level of leafy spurge control after 12 months as spray applications of 1.1 and $2.2 \mathrm{~kg} / \mathrm{ha}$ (Table 1).

Leafy spurge control with roller-applied picloram on September 22, 1978, either alone or with a foam additive usually was similar to that with spray application at 1.1 or $2.2 \mathrm{~kg} / \mathrm{ha}$ after 24 months (Table 1). The exception was roller application at $4.8 \mathrm{~km} / \mathrm{h}$ without the foam additive where leafy spurge control declined more rapidly at 12,21 , and 24 months than with any other treatment. Perhaps, in the absence of the foam additive, the roller applicator was traveling too fast at $4.8 \mathrm{~km} / \mathrm{h}$ for adequate herbicide deposition on leafy spurge. Some grass injury was observed in the first year after treatment, but visible injury was not detected thereafter (data not presented). Leafy spurge control across all picloram treatments averaged 94, 85, 79, and 65\% for the 9-, 12-, 21-, and 24-month evaluations, respectively; these data indicate the typical reestablishment of leafy spurge following picloram application without a retreatment program.

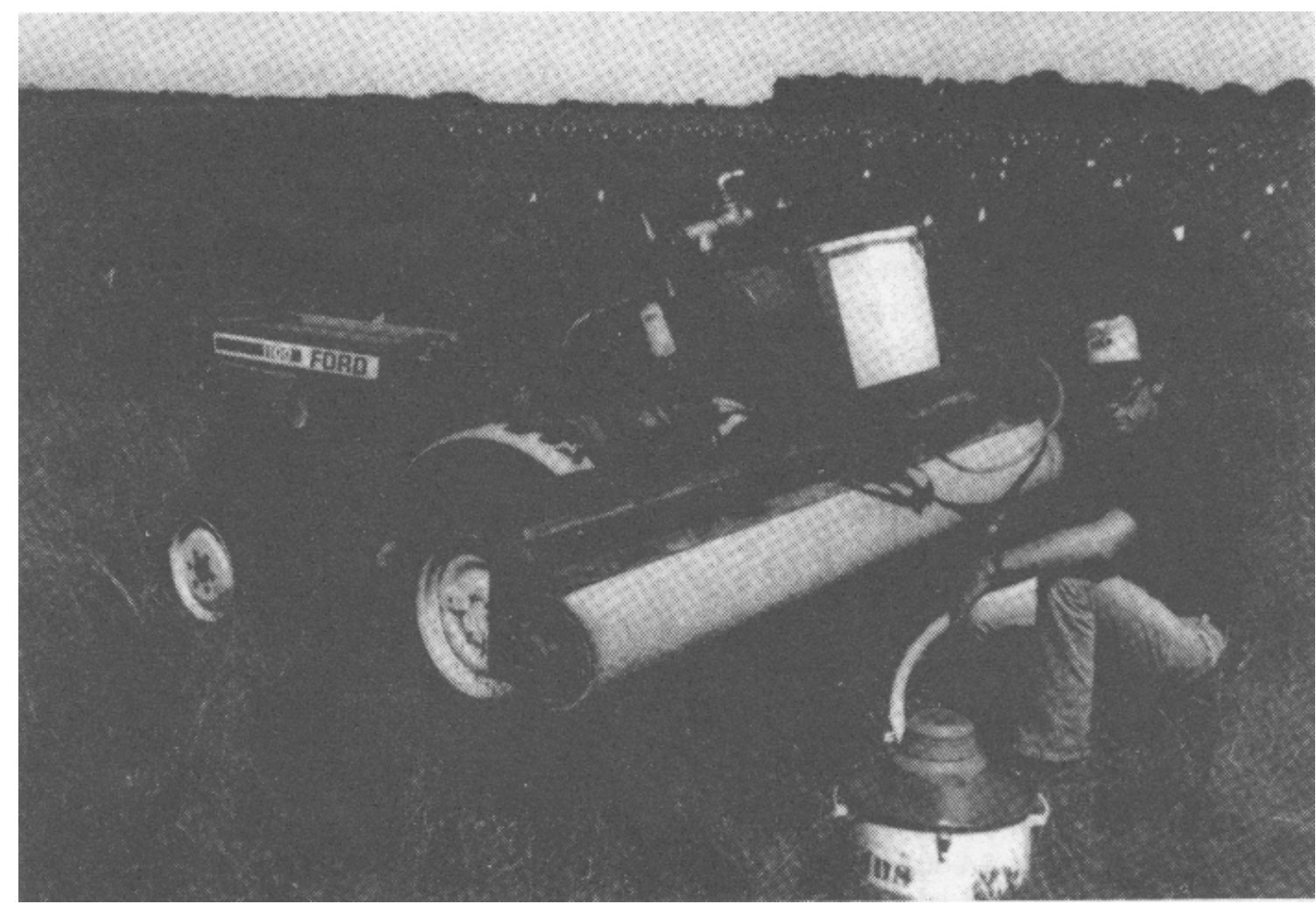

Figure 1. The roller applicator showing carpet-covered roller, herbicide reservoir, and wet vacuum cleaner for cleaning between treatments.

(Editor's note: Picture was poor in original). 
Leafy spurge control by picloram applied with the roller applicator on October 3 , 1979 , generally was better than $1.1 \mathrm{~kg} / \mathrm{ha}$ but not as good as $2.2 \mathrm{~kg} / \mathrm{ha}$ of spray-applied picloram (Table 1). The reduced leafy spurge control in this experiment, compared to earlier experiments, may have been caused by reduced picloram uptake and translocation, since most of the leaves had abscised from the leafy spurge stems. Also, the temperature on treatment day was near $4^{\circ} \mathrm{C}$, and a plant-killing freeze occurred 6 days after treatment. Long soil persistence of picloram probably accounted for the good control from the 2.2 $\mathrm{kg} / \mathrm{h}$ a spray treatment.

Table 1. Leafy spurge control with picloram using the roller applicator on three dates at three locations near Fargo, ND.

\begin{tabular}{|c|c|c|c|c|c|c|c|}
\hline \multirow{3}{*}{$\begin{array}{l}\text { Date and type } \\
\text { of application }\end{array}$} & \multirow{2}{*}{\multicolumn{2}{|c|}{ Picloram }} & \multicolumn{5}{|c|}{ Leafy spurge control } \\
\hline & & & \multicolumn{5}{|c|}{ Months after treatment } \\
\hline & Conc. & Rate $^{a}$ & 9 & 12 & 21 & 24 & 33 \\
\hline & $(\mathrm{g} / \mathrm{L})$ & (kg/ha) & & 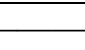 & $-(\%)$ & 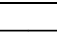 & - \\
\hline \multicolumn{8}{|l|}{ June 21,1978} \\
\hline Roller-4. $8 \mathrm{~km} / \mathrm{h}$ & 30 & $\ldots$ & $\ldots$ & 95 & $\ldots$ & $\ldots$ & $\ldots$ \\
\hline Roller-9.7 km/h & 30 & $\ldots$ & $\ldots$ & 67 & $\ldots$ & $\ldots$ & $\ldots$ \\
\hline Spray & 15 & 1.1 & $\ldots$ & 87 & $\ldots$ & $\ldots$ & $\ldots$ \\
\hline Spray & 30 & 2.2 & $\ldots$ & 96 & $\ldots$ & $\ldots$ & $\ldots$ \\
\hline $\operatorname{LSD}(0.05)$ & & & & 28 & & & \\
\hline \multicolumn{8}{|l|}{ September 22, 1978} \\
\hline Roller-1.6 km/h & 30 & $\ldots$ & 91 & 87 & 82 & 66 & $\ldots$ \\
\hline Roller-4.8 km/h & 30 & $\ldots$ & 94 & 69 & 52 & 36 & $\ldots$ \\
\hline $\begin{array}{l}\text { Roller-1.6 km/h } \\
\text { plus foam }\end{array}$ & 30 & $\ldots$ & 97 & 94 & 94 & 77 & $\ldots$ \\
\hline Roller-4.8 km/h & & & & & & & \\
\hline plus foam & 30 & $\ldots$ & 97 & 88 & 83 & 73 & $\ldots$ \\
\hline Spray & 15 & 1.1 & 88 & 82 & 74 & 65 & $\ldots$ \\
\hline Spray & 30 & 2.2 & 98 & 91 & 88 & 72 & $\ldots$ \\
\hline $\operatorname{LSD}(0.05)$ & & & 9 & 10 & 17 & 23 & \\
\hline \multicolumn{8}{|l|}{ October 3, 1979} \\
\hline Roller-1.6 km/h & 30 & $\ldots$ & 80 & $\ldots$ & 61 & 43 & 32 \\
\hline Roller-3.2 km/h & 30 & $\ldots$ & 77 & $\ldots$ & 70 & 53 & 24 \\
\hline Spray & 15 & 1.1 & 79 & $\ldots$ & 59 & 19 & 6 \\
\hline Spray & 30 & 2.2 & 100 & $\ldots$ & 98 & 96 & 85 \\
\hline $\operatorname{LSD}(0.05)$ & & & 13 & & 19 & 32 & 28 \\
\hline
\end{tabular}

${ }^{a}$ Rate for roller applicator at $4.8 \mathrm{~km} / \mathrm{h}$ is estimated at $0.86 \mathrm{~kg} / \mathrm{ha}$ as determined in the rate per as hectare experiment. ${ }^{\mathrm{b}}$ Boom-end marking foam. 


\section{Application variables}

The initial experiments demonstrated that the roller applicator technique could provide leafy spurge control similar to a spray application but did not delineate the optimum application conditions. The lowest roller-applied picloram concentration that gave adequate leafy spurge control was considered the most efficient. Picloram concentrations of 60 and $120 \mathrm{~g} / \mathrm{L}$ provided the highest leafy spurge control after 2 years (Table 2). However, the $60 \mathrm{~g} / \mathrm{L}$ concentration may be the most efficient mixture, because both 60 and $120 \mathrm{~g} / \mathrm{L}$ concentrations provided similar control through the first year and retreatments would have been recommended for all plots in the second year. Solution concentrations of 15 or $20 \mathrm{~g} / \mathrm{L}$ provided adequate leafy spurge control for less than 1 year An advantage from spring or fall treatments was not detected. The addition of a surfactant, or petroleum oil to picloram solutions did not improve control and there was a trend for reduced control when the additives were used (Table 3). With similar roller-applied treatments in other experiments by these authors (6), picloram plus oil concentrate provided slightly better control than picloram alone when fall applied at one location, but, at three other sites, leafy spurge control was decreased when the oil concentrate was added to picloram. Similarly, leafy spurge control with picloram was not improved by a surfactant or oil additive when using a controlled-droplet applicator (4). Additives have not been included with picloram in subsequent experiments.

Table 2. Leafy spurge control with several picloram concentrations applied with the roller applicator on June 16 and September 2, 1980, near Sheldon and Valley City, ND, respectively.

\begin{tabular}{|c|c|c|c|c|c|c|}
\hline \multirow{4}{*}{$\begin{array}{c}\text { Picloram } \\
\text { concentration }\end{array}$} & \multicolumn{6}{|c|}{ Leafy spurge control } \\
\hline & \multicolumn{6}{|c|}{ Treatment date and months after treatment } \\
\hline & \multicolumn{3}{|c|}{ June 16,1980} & \multicolumn{3}{|c|}{ September 2, 1980} \\
\hline & 12 & 15 & 24 & 9 & 12 & 21 \\
\hline$(\mathrm{g} / \mathrm{L})$ & \multicolumn{6}{|c|}{$\longrightarrow(\%)-$} \\
\hline 15 & 69 & 12 & 6 & 35 & 3 & 2 \\
\hline 20 & 70 & 9 & 4 & 67 & 15 & 6 \\
\hline 30 & 75 & 15 & 17 & 91 & 50 & 15 \\
\hline 60 & 93 & 48 & 40 & 97 & 81 & 34 \\
\hline 120 & 90 & 58 & 59 & 96 & 93 & 65 \\
\hline $\operatorname{LSD}(0.05)$ & 14 & 21 & 30 & 17 & 22 & 32 \\
\hline
\end{tabular}


Table 3. Leafy spurge control with picloram plus additives using the roller applicator on June 16, 1980, near Sheldon, ND, and evaluated 12 months after treatment.

\begin{tabular}{ccccc}
\hline \multirow{2}{*}{$\begin{array}{c}\text { Picloram } \\
\text { concentration }\end{array}$} & \multicolumn{4}{c}{ Leafy spurge control } \\
\cline { 2 - 5 } & None & Surfactant $^{\mathrm{a}}$ & Odditive $^{\mathrm{b}}$ & Mean \\
\cline { 2 - 5 } 15 & $(\mathrm{~g} / \mathrm{L})$ & 53 & $(\%)$ & 43 \\
20 & 46 & 45 & 51 & 43 \\
30 & 48 & 67 & 37 & 66 \\
Mean & 74 & 55 & 56 & \\
LSD (0.05): Concentration $=16 ;$ additive=NS; concentration $\times$ additive $=27$ & 48 & \\
\hline
\end{tabular}

a $2.5 \%$ surfactant $(\mathrm{v} / \mathrm{v})$.

${ }^{\mathrm{b}} 5 \%$ oil (v/v) (83\% paraffin-base petroleum oil plus $15 \%$ emulsifier).

Treatment of leafy spurge with the roller applicator set as low as the terrain would permit (low) generally provided better leafy spurge control than treating the upper 50\% of the plants only (high) regardless of time of year or solution concentration (Table 4). Leafy spurge control at the low applicator height generally was better for the September than July treatment time. The $30 \mathrm{~g} / \mathrm{L}$ solution was the most efficient in this study, since leafy spurge control generally was similar for the three picloram concentrations.

Table 4. Leafy spurge control with several picloram concentrations using the roller applicator at two heights applied on July 8 and September 1, 1981, near Sheldon, ND.

\begin{tabular}{|c|c|c|c|c|c|}
\hline \multirow{4}{*}{$\begin{array}{l}\text { Time of } \\
\text { application }\end{array}$} & \multirow{4}{*}{$\begin{array}{l}\text { Picloram } \\
\text { concentration }\end{array}$} & \multicolumn{4}{|c|}{ Leafy spurge control } \\
\hline & & \multicolumn{4}{|c|}{ Evaluation date and roller height $\mathrm{t}^{\mathrm{a}}$} \\
\hline & & \multicolumn{2}{|c|}{ June 1982} & \multicolumn{2}{|c|}{ August 1982} \\
\hline & & Low & High & Low & High \\
\hline & $(g / L)$ & & 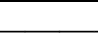 & 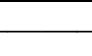 & \\
\hline \multirow[t]{3}{*}{ July 8,1981} & 30 & 11 & 6 & 12 & 0 \\
\hline & 40 & 14 & 6 & 9 & 2 \\
\hline & 60 & 38 & 5 & 5 & 3 \\
\hline Mean & & 21 & 6 & 9 & 2 \\
\hline \multirow[t]{3}{*}{ September 1,1981} & 30 & 64 & 18 & 56 & 1 \\
\hline & 40 & 88 & 8 & 34 & 2 \\
\hline & 60 & 60 & 13 & 37 & 5 \\
\hline Mean & & 71 & 13 & 42 & 3 \\
\hline June LSD (0.05): & \multicolumn{5}{|c|}{$\begin{array}{c}\text { Concentration }=25 ; \text { height }=20 ; \text { height } \times \text { concentratration }=32 ; \\
\text { time } \times \text { height } \times \text { concentration }=14\end{array}$} \\
\hline August LSD (0.05): & \multicolumn{5}{|c|}{$\begin{array}{c}\text { Concentration }=11 \text {; height }=9 \text {; height } \times \text { concentration }=22 \text {; } \\
\text { time } \times \text { height } \times \text { concentration }=6\end{array}$} \\
\hline
\end{tabular}

${ }^{a}$ Roller height was adjusted to treat the top half of most leafy spurge plants (high) or as near to the soil surface as terrain would permit (low). 


\section{Rate of picloram applied per hectare}

The roller applicator applied picloram at $0.67,0.74,0.99$, and $1.04 \mathrm{~kg} / \mathrm{ha}$ at four locations for an average application rate of $0.86 \mathrm{~kg} / \mathrm{ha}$ (data not presented). The spray applicator applied the maximum recommended rate of picloram $(2.2 \mathrm{~kg} / \mathrm{ha})$ in $80 \mathrm{~L} / \mathrm{ha}$. Both applicators were compared using the same travel speed and herbicide concentration, and the sprayer had relatively low-volume nozzle tips. Thus, the roller applicator applied $60 \%$ less herbicide than the spray applicator under similar conditions. The amount of herbicide applied with a roller applicator is affected primarily by weed density, applicator height, and difference in height between the weed and crop, so herbicide usage would vary substantially from location to location. Herbicide usage savings generally would exceed $60 \%$ in leafy spurge-infested pastures since only patches with $80 \%$ or more leafy spurge cover were selected as experimental sites.

\section{Picloram residues}

Leafy spurge control with picloram generally was similar for both spray and roller applications. This suggested that translocation of the herbicide was the primary factor in control and that persistence of picloram in the soil was a comparatively minor contributor to long-term control. It was expected that soil from plots treated with roller-applied picloram would have little, if any, herbicide residue. However, in 1980, picloram residues from roller applications of 15, 30, 60, and $120 \mathrm{~g} / \mathrm{L}$ were similar to, or slightly higher than, the picloram residue from a spray application of $1.1 \mathrm{~kg} /$ ha (Table 5). The roller application of picloram at $40 \mathrm{~g} / \mathrm{L}$ (high) and $60 \mathrm{~g} / \mathrm{L}$ (low) in June 1981 resulted in residues after 14 weeks similar to $1.1 \mathrm{~kg} / \mathrm{ha}$ spray applied after 19 weeks in 1980 . There was a lower picloram residue in the soil 14 weeks after application in 1981 than 19 weeks after application in 1980. Less rainfall was received in 1980 than in 1981, which probably accounted for reduced picloram decomposition in 1980. Picloram residues from the August 1981 treatments with roller applications of 30,40, and $60 \mathrm{~g} / \mathrm{L}$ at the low height were similar to or slightly higher than those found after 6 weeks with a picloram spray applied at $0.6 \mathrm{~kg} / \mathrm{ha}$. The residue was low when leafy spurge received the high roller treatments in June or August 1981.

The high level of picloram in the soil after roller application was unexpected. The herbicide may reach the soil by washing off the foliage, plant decomposition, and direct exudation from the leafy spurge root tissue. High residue levels would limit the adoption of the roller applicator for leafy spurge control on cropland or around trees.

Roller application of picloram for leafy spurge control was most effective when the applicator was adjusted to treat as much of the plant as possible. A picloram solution concentration of between 30 and $60 \mathrm{~g} / \mathrm{L}$ was most efficient. Generally, leafy spurge control was not enhanced by including an oil or surfactant additive. Fall application tended to provide the best leafy spurge control when other variables, such as applicator height, were optimal. However, contrary to initial expectations, picloram residues in soil after roller application were similar to those for comparable rates of the spray-applied herbicide.

Page 8 of 10 
Table 5. Picloram residue in the soil after roller and spray applications in 1980 and 1981 near Fargo, ND, as determined with a sunflower bioassay.

\begin{tabular}{|c|c|c|c|c|c|}
\hline \multicolumn{2}{|c|}{ Application } & \multicolumn{2}{|c|}{ Picloram } & \multirow{2}{*}{$\begin{array}{l}\text { Time after } \\
\text { application }\end{array}$} & \multirow{2}{*}{$\begin{array}{c}\text { Picloram } \\
\text { residue }\end{array}$} \\
\hline Method & Height $^{\mathrm{a}}$ & Conc. & Rate $^{b}$ & & \\
\hline & & $(\mathrm{g} / \mathrm{L})$ & (kg/ha) & (weeks) & (ppmw) \\
\hline \multicolumn{6}{|c|}{ Applied June 1980} \\
\hline Roller & High & 15 & 0.4 & 19 & 0.05 \\
\hline Roller & High & 20 & 0.5 & 19 & $<0.01$ \\
\hline Roller & High & 30 & 0.8 & 19 & 0.03 \\
\hline Roller & High & 60 & 1.6 & 19 & 0.06 \\
\hline Roller & High & 120 & 3.1 & 19 & 0.07 \\
\hline Spray & $\ldots$ & 15 & 1.1 & 19 & 0.03 \\
\hline Spray & $\ldots$ & 30 & 2.2 & 19 & 0.17 \\
\hline $\operatorname{LSD}(C$ & & & & & 0.03 \\
\hline \multicolumn{6}{|c|}{ Applied June 1981} \\
\hline Roller & High & 30 & 0.8 & 14 & $<0.01$ \\
\hline Roller & Low & 30 & 0.8 & 14 & $<0.01$ \\
\hline Roller & High & 40 & 1.0 & 14 & 0.03 \\
\hline Roller & Low & 40 & 1.0 & 14 & $<0.01$ \\
\hline Roller & High & 60 & 1.6 & 14 & $<0.01$ \\
\hline Roller & Low & 60 & 1.6 & 14 & 0.08 \\
\hline $\operatorname{LSD}(C$ & & & & & 0.02 \\
\hline \multicolumn{6}{|c|}{ Applied August 1981} \\
\hline Roller & High & 30 & 0.8 & 6 & 0.04 \\
\hline Roller & Low & 30 & 0.8 & 6 & 0.27 \\
\hline Roller & High & 40 & 1.0 & 6 & $<0.01$ \\
\hline Roller & Low & 40 & 1.0 & 6 & 0.21 \\
\hline Roller & High & 60 & 1.6 & 6 & $<0.01$ \\
\hline Roller & Low & 60 & 1.6 & 6 & 0.19 \\
\hline Spray & $\ldots$ & 4 & 0.3 & 6 & 0.10 \\
\hline Spray & $\ldots$ & 6 & 0.4 & 6 & 0.12 \\
\hline Spray & $\ldots$ & 8 & 0.6 & 6 & 0.18 \\
\hline LSD & & & & & 0.05 \\
\hline
\end{tabular}

${ }^{\mathrm{a}}$ Roller height was adjusted to treat the top half of most leafy spurge plants (high) or as near to the soil surface as terrain would permit (low).

${ }^{b}$ Rates for roller applicator are estimated based on $60 \%$ reduction of herbicide use compared to a spray application at $80 \mathrm{~L} / \mathrm{ha}$ as determined in rate per hectare experiments. 


\section{Literature cited}

1. Carlson, D. R. 1977. Use of the recirculating sprayer for selective control of common milkweed. Proc. North Cent. Weed Control Conf. 32:110-112.

2. Field, D. D. 1977. Gravity-fed recirculating sprayers. Proc. North Cent. Weed Control Conf. 32:146-148.

3. Heady, H. F. 1975. Rangeland Management. McGraw-Hill Book Co., New York.

4. Lym, R. G. and C. G. Messersmith. 1981. Leafy spurge control using the controlled droplet applicator with picloram plus additives. North Cent. Weed Control Conf. Res. Rep. 38:48-49.

5. McWhorter, C. G. 1970. A re-circulating sprayer system for post-emergence weed control in row crops. Weed Sci. 18:285-287.

6. Messersmith, C. G. and R. G. Lym. 1981. Long term management of leafy spurge in pasture and rangeland-year one. North Cent. Weed Control Conf. Res. Rep. 38:38-40.

7. National Research Council. 1968. Principles of Plant and Animal Pest Control. II. Weed Control. National Academy of Science. Publ. 1597.

8. Santelmann, P. W. 1977. Herbicide bioassay. Pages 79-87 in B. Truelove, ed. Research Methods in Weed Science, 2nd ed., South Weed Sci. Soc., Auburn, AL.

9. Schepers, J. S. and O. C. Burnside. 1979. Electronic moisture sensor for maintaining herbicide solution on a roller applicator. Weed Sci. 27:559-561.

10. Vallentine, J. F. 1971. Range Development and Improvements. Brigham Young Univ. Press, Provo, UT.

11. Wyse, D. L. and C. Habstritt. 1977. A roller herbicide applicator. Proc. North Cent. Weed Control Conf. 32:144-145. 